This item was submitted to Loughborough's Research Repository by the author.

Items in Figshare are protected by copyright, with all rights reserved, unless otherwise indicated.

\title{
Postgraduate events as a building block for interdisciplinary research
}

PLEASE CITE THE PUBLISHED VERSION

http://dx.doi.org/10.1111/area.12227

\section{PUBLISHER}

(c) Wiley

\section{VERSION}

AM (Accepted Manuscript)

\section{PUBLISHER STATEMENT}

This work is made available according to the conditions of the Creative Commons Attribution-NonCommercialNoDerivatives 4.0 International (CC BY-NC-ND 4.0) licence. Full details of this licence are available at: https://creativecommons.org/licenses/by-nc-nd/4.0/

\section{LICENCE}

CC BY-NC-ND 4.0

\section{REPOSITORY RECORD}

Darlington, Eleanor F., Catherine Waite, and Stacey Balsdon. 2019. "Postgraduate Events as a Building Block for Interdisciplinary Research". figshare. https://hdl.handle.net/2134/19051. 


\section{Postgraduate events as a building block for interdisciplinary research}

\section{Journal: Area}

Authors: Darlington, EF., Waite, A., and Balsdon, SL

The early stages of a research career are a flurry of learning, data collection and writing activity. Postgraduate researchers (PGRs) are under increasing pressure to publish, secure funding and develop networks within their chosen field, in order to secure a job and further their academic careers; even before they have submitted their PhD thesis. Interdisciplinary engagement with other academics, practitioners and the general public is imperative to tackle complex issues with an inherently geographical focus, ranging from climate change through to immigration (Ziegler et al. 2013). The longstanding debates regarding disciplinary identity and unity within geography, were rejuvenated in the landmark paper from Harrison et al. (2004), who called for greater exploration, and creation of, interdisciplinary linkages. Here we expand upon recent debates of interdisciplinarity and explore them within the context of postgraduate events. PGRs inhabit a postdisciplinary landscape: outdated disciplinary structures remain, yet its demise brings valuable intellectual freedom (Gregson, 2003). Maturing within this research context of rapid flux, their perceptions towards interdisciplinary research are important, not only for the future development of geography, but also for those allied disciplines with which geographers interact. 
Recognising that research requires a specialism is important, yet the holistic nature of geography makes it ideally placed to facilitate interdisciplinary research (Gillen et al. 2014). Expanding from the confines of a single discipline enables many contemporary research questions to be conceptualised or addressed. Interdisciplinarity is conceptualised here as the linkages between the natural sciences, social sciences and the humanities (Lau and Pasquini, 2008). Engagement with interdisciplinary research can potentially accrue skill sets spanning educational (conceptual and methodological innovation), cultural, social, and career development. However, this comes at the expense of potential loss of academic identity and greater time investment, posing additional challenges for PGRs to negotiate. Factoring in time to nurture and establish effective communication within interdisciplinary scenarios is vital to drive research forward (Braken and Oughton 2006). A richer and deeper geographical knowledge can be obtained by overcoming practical boundaries, such as the language differences between social and physical sciences (Horner 2014). Nurturing PGRs to embrace interdisciplinarity challenges the academic status quo by increasing the distance from discipline solidarity. But, those that embrace it can enhance critical thinking, boost creativity and develop communication skills which are highly valued, providing opportunities for future employment (Gillen et al. 2014).

Recognising the growing momentum and interest in the interdisciplinary nature of geographical research (Kraftl et al. 2015), the authors of this commentary sought to gauge PGR views on it through interactions (feedback questionnaire) at a 
postgraduate geography conference in the UK. The meeting was conceived to comprise of broad geographical themes that crossed traditional sub-discipline specialisms, and meant that nominally 'human' and 'physical' geographers would present papers and discuss explicitly interdisciplinary themes in the same sessions. This thematic approach extended into the workshop sessions, which addressed the challenges of PGR funding and publishing. To assess the perception of interdisciplinary research among this cross section of geography PGRs, results from an anonymous post-conference survey are presented. Almost fifty percent of delegates $(n=37)$ responded to the survey which explored four themes: i) delegate background (stage of research and how they described their disciplinary background); ii) engagement/participation in the conference (e.g. presentation of a paper, workshop involvement); iii) perceptions regarding networking opportunities during the conference; iv) impressions regarding the value of the conference including its interdisciplinary nature. Approximately $60 \%$ of respondents were in the first year of their PhD research (Table 1), probably unsurprising given the event provided an opportunity for PGRs to present research in progress.

\begin{tabular}{lcccc}
\hline \multicolumn{1}{c}{ Discipline } & $\begin{array}{c}\text { Human } \\
\text { Geographer }\end{array}$ & $\begin{array}{c}\text { Physical } \\
\text { Geographer }\end{array}$ & $\begin{array}{c}\text { Interdisciplinary } \\
\text { Researcher }\end{array}$ & Other \\
\hline Career Stage & & & & \\
\hline MSc & $3 \%$ & & $3 \%$ & $3 \%$ \\
\hline $1^{\text {st }}$ Year PhD & $35 \%$ & $16 \%$ & & \\
\hline $2^{\text {nd }}$ Year PhD & $14 \%$ & $5 \%$ & & \\
\hline $3^{\text {rd }}$ Year PhD & $16 \%$ & $3 \%$ & & \\
\hline $4^{\text {th }}$ Year PhD & $3 \%$ & & & \\
\hline
\end{tabular}


Table 1: Career stage and self-identified disciplinary label of respondents who completed the conference questionnaire.

Following the conference, delegates were asked to self-identify their disciplinary affiliation (Table 1) and an absence of awareness or association with interdisciplinary research persisted. Given the prominence of first year PhD students, it might be anticipated that they remain focused on exploring their own 'specialism'. However, being exposed to a diverse audience provided an opportunity to present to non-specialists, engage in conversation and networking, and encouraged delegates to place their specialism within a wider research context (Ziegler et al. 2013). This may ultimately stimulate collaborative research, thus increasing future opportunities, and the visibility of results (Lee and Bozeman 2005).

Engagement with other disciplines as a PGR could facilitate the development of new ideas and research approaches, which may accrue lasting benefits for a research career. This was certainly true for delegates who discovered new data collection methods and ways to consider their data. During doctoral training, individuals are encouraged to develop a large portfolio of transferable skills (Vitae, 2009). In addition, many UK Research councils are increasingly calling for collaborative and interdisciplinary research (Wainwright et al. 2014). One workshop at the conference focused on interdisciplinary funding opportunities. Whilst recognising the importance of specialism, delegates appreciated the opportunity to view their research in different ways which could potentially enable them to access a 
wider source of funding. This wider knowledge of other sub-disciplines within geography and beyond could help facilitate successful, high impact research grants, due to their interdisciplinary nature.

While PGRs have time to experiment with new innovative and cutting edge technologies, they are ideally placed to explore interdisciplinary research (Niopek et al. 2011; Horner et al. 2014). Once the research is complete, ensuring it reaches the right audience is imperative. However, the publishing culture divides geography. Physical geographers typically perceive their primary publication outlets to be in 'science' journals, whilst human geographers typically publish in 'human' geography/social sciences journals. There is value in specialist journals, but the profile of 'geographical journals' needs to be raised to encourage more interdisciplinary submissions, reflecting the true nature of the discipline and the wider research landscape.

As a PGR, spending time broadening horizons for cultural gain may not be a priority given the pressure to complete the thesis on time, responding to increasing funding constraints. Yet interdisciplinary knowledge is important for those teaching and lecturing, which is especially true in the delivery of University level tutorials and core skill modules that span geography (Pharo et al., 2012). Beyond academia, employers value lateral thinking and the ability to digest information beyond subject specific specialisms. Interdisciplinary research requires solid communication skills and innovative thinking, both of which are highly sought after skills by employers (NERC 2012). 
Geography PGRs who are provided with the time and intellectual space at the outset of their careers to embrace interdisciplinary research gain transferable skills, personal development training and potentially enhanced employability. Insights provided in this commentary demonstrate that there is scope for further research on understandings and practices of interdisciplinarity amongst PGRs and other early career researchers. It would seem that encouraging PGRs to build upon and develop an interdisciplinary research ethos will enhance discipline diversity and stimulate innovative methodologies. Improved knowledge transfer across the discipline is essential to address inextricably interlinked human, environmental and physical geography research questions.

\section{Acknowledgments}

The authors thank the organisers and participants of the RGS-IBG Postgraduate Forum Mid-Term conference, hosted by the Department of Geography, Loughborough University, in 2014.

\section{References}


Bracken L, and Oughton E 2006 'What do you mean?' The importance of language in developing interdisciplinary research Transactions of the Institute of British Geographers 31 371-382

Gillen J, Ziegler A, Friess D, and Wasson R 2014 Geography's role in nurturing postgraduate students The Geographical Journal doi: 10.1111/geoj.12100

Gregson N 2003 Discipline games, disciplinary games and the need for a postdisciplinary practice: responses to Nigel Thrift's 'The future of geography' Geoforum 34(1) 5-7

Harrison S, Massey D, Richards K, Magilligan F, Thrift N, and Bender B 2004 Thinking across the divide: perspectives on the conversations between physical and human geography Area 36 435-442

Horner R 2014 Postgraduate encounters with sub-disciplinary divides: entering the economic/development geography trading zone Area 464 435-442

Kraftl P, Datta K, and Wood P 2015 Editorial. Area 47 2-3

Lau L, and Pasquini M 2008 'Jack of all trades'? The negotiation of interdisciplinarity within geography. Geoforum 39(2) 552-560 
Lee S, and Bozeman B 2005 The impact of research collaboration on scientific productivity Social studies of science 35 673-702

NERC 2012 NERC postgraduate and professional skills needs review (http://www.nerc.ac.uk/skills/postgrad/policy/skillsreview/2012/skills-

framework.pdf) Accessed 21 October 2014

Niopek D, Berrens R, Mockenhaupt S, Lewis M, Mueller A, and Grimm D 2011 To go or not to go, that is the question - Six personal reflections on how geographic mobility may affect your career and life BioEssays $33728-731$

Pharo J, Davison A, Warr K, Nursey-Bray M, Beswick K, Wapstra E, and Jones C 2012 Can teacher collaboration overcome barriers to interdisciplinary learning in a disciplinary university? A case study using climate change. Teaching in Higher Education 17 497-507

Vitae 2009 The Vitae Researcher Development Framework (https://www.vitae.ac.uk/researchers-professional-development/about-the-vitaeresearcher-development-framework/developing-the-vitae-researcher-developmentframework) Accessed 10 December 2014 
Wainwright E, Barker J, Ansell N, Buckingham S, Hemming P, and Smith F 2014 Geographers out of place: institutions, (inter)disciplinary and identity Area 46410 417

Ziegler A, Gillen J, Newell B, Grundy-Warr C, and Wasson R 2013 Comprehensive research in geography Area 45 252-254 